\title{
Melting Pot: \\ An ambiguous series combining minority and majority discourses
}

\author{
Sarah Sepulchre \\ Université Catholique de Louvain
}

\section{Introduction}

On 17 April 2007, the first episode of Melting Pot Café (more widely known as Melting Pot) was broadcast on La Une, the first TV channel of the RTBF. Melting Pot is the story of Astrid who tries to save her pub from bankruptcy. As we will see, the Melting Pot is a pub catering to genuine Bruxellois (name of the people living in Brussels), newcomers from Belgium and from abroad, French-speaking and Flemish people. The first episode thus came only four months after Bye Bye Belgium, a fake news broadcast in which Belgium's leading anchorman announced that the country was splitting. This hoax was aired by the RTBF on 13 December 2006. The series was thus already in post-production at a time when Belgium's identity became a prominent issue in the media.

Does the series reflect theses questions? What kind of representation does Melting Pot offer? We will first situate the RTBF in the Belgian media landscape and try to figure out if it belongs to the minority media. We will then present the RTBF as a fiction producer and broadcaster. We will see that Belgian television channels are not particularly representative of the diversity of the Belgian population. Finally, our examination of this series will focus on three points of analysis: the characters, the themes and the symbolic identities represented by the Melting Pot pub.

\section{The RTBF and the minority media}

The RTBF is the public broadcaster in the French-speaking part of Belgium. With the federalisation of the country, three communities were created to represent the three national languages in Belgium: the Flemish, the German and the French. To simplify, Brussels, as a self-governed territory in Belgium, is linked to both the Flemish and the francophone communities. Since 1977, each community has therefore had its own public broadcaster: the Radio Télévision belge de la Communauté française (RTBF), the Belgischer Rundfunk (BRF) and the Vlaamse Radio en Televisieomroeporganisatie (VRT). These only broadcast in their own territory, which means that a Walloon does not receive the VRT and a Fleming cannot watch the RTBF. 
The RTBF group owns three channels: La Une, La Deux and La Trois. Melting Pot Café (also known as Melting Pot) was broadcast on the first channel, La Une, during the prime time slot. This channel is the group's lead channel broadcasting non-specialised programmes for all audiences. In its annual report (2011: 12), the RTBF describes La Deux as the channel for TV series. This is true of American series such as Without a Trace, Boardwalk Empire or Law \& Order, but European series are generally broadcast on the first channel. This scheduling choice gave more publicity to the series, and also reflected the need to meet a legal requirement: as a public channel, the RTBF has to broadcast 55\% European programmes and $35 \%$ programmes in French, and at least $50 \%$ of the fiction it broadcasts must be from Europe (CSA, 2012: 15).

As a public broadcaster, can the RTBF be called a minority media outlet? French is one of the national languages in Belgium. From that viewpoint, it is difficult to consider French-speaking Belgians as a real minority. However, French speakers are less numerous than Flemishspeakers in Belgium. According to the Federal State's latest figures from 2011, Belgium has a population of nearly 11 million people. Ten percent of the population lives in the Brussels Region, 58\% in Flanders and 32\% in the Wallonia (Table 1).

Table 1. Belgian population in 2011

\begin{tabular}{|l|l|l|}
\hline Location & Population & $\mathbf{0}$ \\
\hline Brussels region & $1,119,088$ & 10.2 \\
\hline Flanders & $6,306,638$ & 57.6 \\
\hline $\begin{array}{l}\text { Wallonia } \\
\text { (Including the German } \\
\text { Community) }\end{array}$ & $3,525,540$ & 32.2 \\
& $(75,716)$ & $(0.7)$ \\
\hline Total & $\mathbf{1 0 , 9 5 1 , 2 6 6}$ & $\mathbf{1 0 0}$ \\
\hline
\end{tabular}

Source: Directorate-general Statistics and Economic information http://statbel.fgov.be/fr/modules/publications/statistiques/population/p opulation - chiffres population 1990-2011.jsp

It impossible to know exactly how many Belgians speak French, Flemish or German as their mother tongue, as linguistic censuses are forbidden in Belgium. Flemish speakers are thought to represent between 57 and $60 \%$ of the population and French speakers 40 to $43 \%$ (Table 2). It is estimated that between 80 and $90 \%$ of the population of Brussels is French-speaking.

Table 2. Languages spoken in Belgium 


\begin{tabular}{|l|l|l|}
\hline & Flemish & French \\
\hline In Belgium & $57-60 \%$ & $40-43 \%$ \\
\hline In Brussels & $10-20 \%$ & $80-90 \%$ \\
\hline
\end{tabular}

Source: http://fr.wikipedia.org/wiki/Belgique

The RTBF broadcasts in Brussels and in the Wallonia for Frenchspeakers. Strictly speaking, it is therefore the media outlet of one of the minorities in Belgium (the other minority being the German-speakers, and the majority being the Flemish). However, as the TV channels are only broadcast in their own territory, within the French community the RTBF is seen as a majority media outlet and as the national television broadcaster.

\section{The RTBF as a fiction producer and broadcaster}

The RTBF is not a powerful player in the fiction market in the world and in Europe. In March 2009, the European Audiovisual Observatory stated that American fiction was still overwhelmingly dominant on European television screens, though in decline. In 2007, the year studied by the report, nearly $40 \%$ of the fiction programmes broadcast by the public channels in Europe were of non-European origin. The percentage was higher for the private channels, which broadcast more than $76 \%$ non-European fiction. The French Community in Belgium broadcast $60 \%$ non-European fiction, 38\% European but non-national fiction and $0.7 \%$ national fiction, which was the second worst figure in Europe after Luxembourg (Figure 1). The RTBF is virtually the only TV broadcaster in Belgium to produce TV series. Sometimes the RTL group co-produces series, but not on a regular basis. 
Figure 1. Origin of fiction broadcast by the principal TV channels in 15 European countries in 2007

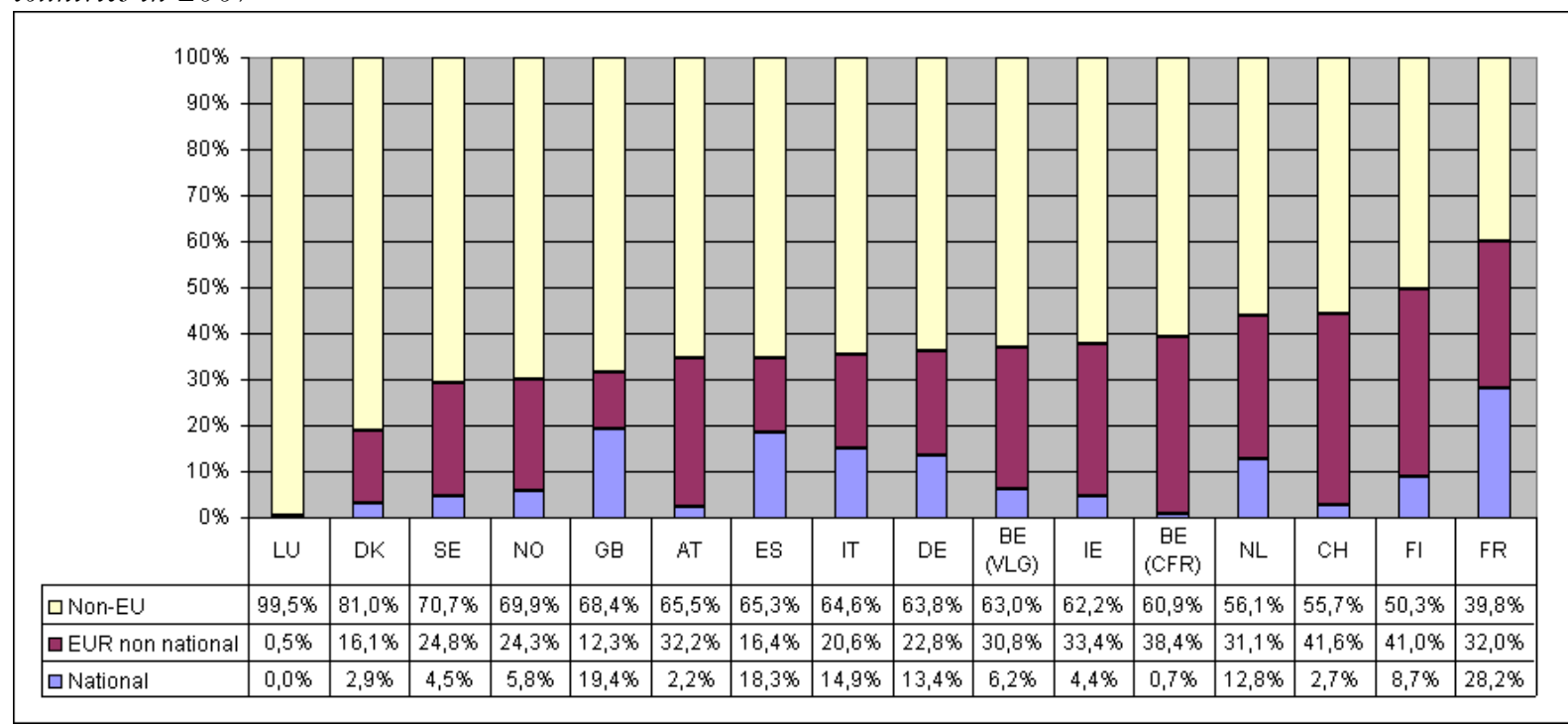

Source: the European Audiovisual Observatory

http://www.obs.coe.int/about/oea/pr/a08vol2.html

In its 2010 annual report, the RTBF gives similar figures for the fiction broadcast on its various channels (Figure 2). Movies and 26-minute series come mainly from the United States of America (in blue) and from European countries (in purple). Fifty-two and ninety-minute series also come from the United States of America and European countries but in reverse proportions. The Belgian output is in yellow and it represents less than $10 \%$ of the fiction broadcast on the RTBF. 
Figure 2. Origins of fictions broadcast in 2010

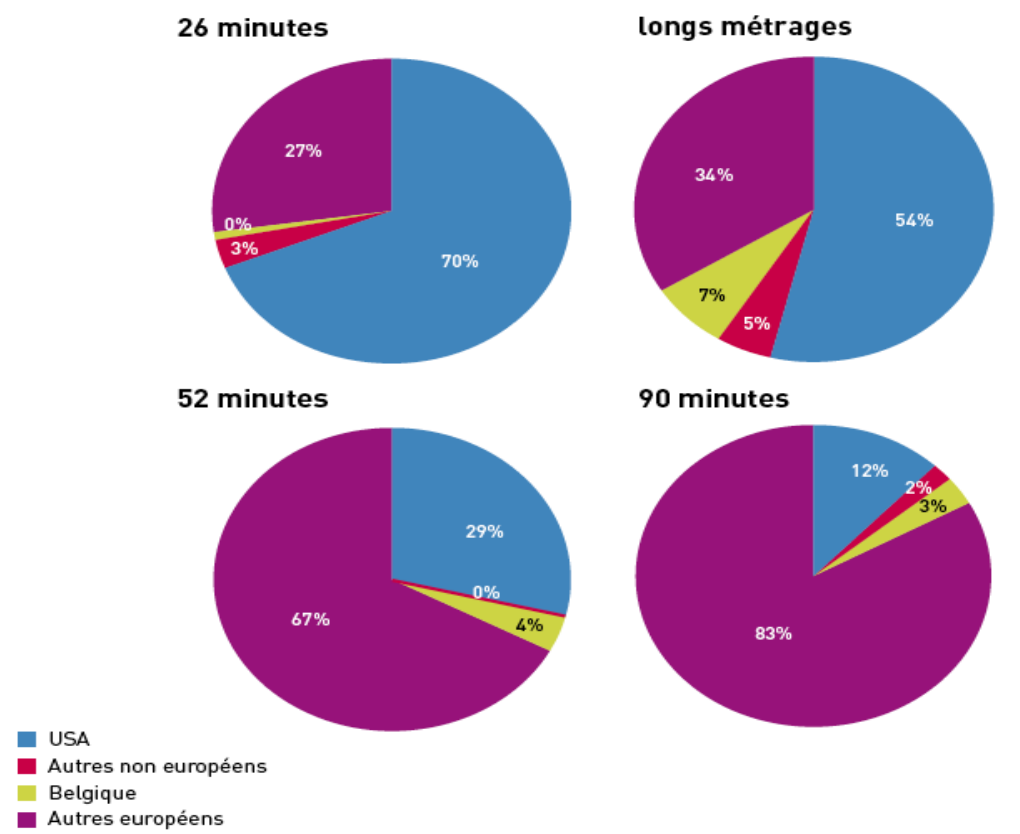

Source: RTBF 2010 Annual Report, p. 29.

http://ds.static.rtbf.be/article/pdf/rtbf ra2010 1-1310718143.pdf

One explanation of this lack of fiction production is that it is too expensive. The annual budget of the RTBF is not very high, at $€ 266$ million in 2006, €272 million in 2007 and €284 million in 2008 (Table 3). The RTBF is a public broadcaster, funded mainly (70\%) by the Walloon government. Income from advertising represents around 20\% and cannot exceed $25 \%$ of the total income by law.

The market is too small in Belgium for fiction production to be profitable. And on the secondary market, the sale of these fiction productions abroad, Belgium has to compete with the French output that is better funded. However, this financial explanation is not completely convincing, given that, as can be seen from Figure 1, 6.2\% of the fiction broadcast by the Flemish television broadcasters is produced in Flanders.

Table 3. Income of the RTBF

\begin{tabular}{|l|l|l|l|}
\hline (millions of euros) & $\mathbf{2 0 0 6}$ & $\mathbf{2 0 0 7}$ & $\mathbf{2 0 0 8}$ \\
\hline Government endowment & 186.59 & 193.18 & 203.38 \\
\hline Income from advertising & 56.19 & 56.68 & 59.34 \\
\hline Other income & 23.83 & 23.09 & 21.28 \\
\hline
\end{tabular}

This work is licensed under a Creative Commons Attribution 3.0 License 


\begin{tabular}{|l|l|l|l|}
\hline Total & 266.61 & 272.95 & 284.00 \\
\hline
\end{tabular}

Source: État des lieux des médias d'information en Belgique francophone (2011), p. 76

http://egmedia.pcf.be/wpcontent/uploads/2011/03/EGMI EDL fullv6 5.pdf

In this financial situation, the fact that the RTBF has produced three series during the last five years is quite a miracle. The last series before that was produced and broadcast in the 1980s. It is obvious that the RTBF is still searching for the right format for its series. The first one, of the three recent series, Septieme Ciel Belgique, lasted for two seasons of twelve episodes (the RTBF hoped to sell it abroad as a standard twentyfour-episode series). Melting Pot follows a more traditional European format, with seasons of six episodes. A Tort ou à Raison is not exactly a series in format. Each story is divided into two episodes meaning that, so far, four stories have been broadcast. As a result, it seems more like a collection of mini-series than a series.

Table 4. Series produced by the RTBF

\begin{tabular}{|l|l|l|l|l|l|}
\hline Series & $\begin{array}{l}\text { no of } \\
\text { season }\end{array}$ & $\begin{array}{l}\text { no of } \\
\text { episodes }\end{array}$ & Format & $\begin{array}{l}\text { Years of } \\
\text { production }\end{array}$ & Genre \\
\hline $\begin{array}{l}\text { Septième } \\
\text { Ciel } \\
\text { Belgique }\end{array}$ & 2 & $24(2 \times 12)$ & 52 min. & $2006-2007$ & Comedy \\
\hline $\begin{array}{l}\text { Melting } \\
\text { Pot Café }\end{array}$ & 3 & $18(3 \times 6)$ & 52 min. & $2007-2010$ & Comedy \\
\hline $\begin{array}{l}\text { A Tort ou } \\
\text { à Raison }\end{array}$ & - & $8(4 \times 2)$ & 52 min. & $\begin{array}{l}2009(2) \\
2012(6) \\
\text { Still } \\
\text { produced }\end{array}$ & Drama \\
\hline
\end{tabular}

As the only series produced during a three-year period by the RTBF, Melting Pot was the only fiction representing French-speaking Belgians on television in Belgium, in Europe, or in the world. We will try to verify what kind of representations are conveyed by Melting Pot, and whether it mirrors the particular situation of French-speakers and other minorities in Belgium. Before going further with this analysis, it seems important to clarify the relation between Belgian television and diversity.

\section{Belgian television and the representation of minorities}

Belgian television in the French area is not recognised for the diversity of its representations. The body supervising audiovisual media in Wallonia has published a barometer of diversity for the last two years. The

This work is licensed under a Creative Commons Attribution 3.0 License 
typical person shown on Belgian television, including the RTBF, is male, white, a member of the higher socio-professional categories, a member of the active population (between 19 and 49 years old) and not suffering from any visible disability. The figures are better in 2012 than in 2011, but are still far from balanced (Table 5).

Table 5. The typical protagonist on Belgian television is...

\begin{tabular}{|c|c|c|c|}
\hline Characteristics & 2012 & 2011 & \\
\hline Male & $66.48 \%$ & $68.54 \%$ & \\
\hline White & $86.04 \%$ & $89.74 \%$ & $\begin{array}{l}\text { Including } \\
\text { 2012)... } \\
\text { Blacks: } 43.03 \% \\
\text { Arabs: } 22.9 \% \\
\text { Asian: } 11.42 \%\end{array}$ \\
\hline $\begin{array}{l}\text { Higher socio- } \\
\text { professional } \\
\text { category }\end{array}$ & $46 \%$ & $46.17 \%$ & \\
\hline \multirow[t]{2}{*}{ Adult } & $30.46 \%$ & $37.13 \%$ & \\
\hline & $26.61 \%$ & $30.91 \%$ & \\
\hline $\begin{array}{l}\text { Without } \\
\text { disability }\end{array}$ & $99.7 \%$ & $99.67 \%$ & \\
\hline
\end{tabular}

Source: Baromètre de la diversité 2012 (CSA) http://www.csa.be/documents/1712

Of course, this does not tell us anything about the languages spoken by these persons, as this is not an indicator studied by the research. Nor does it tell us anything about the nationality of these persons or the Region they belong to. But it indicates that television does not really represent the diversity of the Belgian population, and probably that topics and issues linked to diversity have little chances of coverage on screen.

Fiction follows the same pattern (Table 6), although the position of the white, rich, young male is less dominant. The only difference is the fact that the most represented professions belong to the service and sales category.

Table 6. The typical protagonist in fiction

\begin{tabular}{|l|l|l|l|}
\hline Characteristics & $\begin{array}{l}\text { The main } \\
\text { protagonist }\end{array}$ & Others & \\
\hline Sex & $\begin{array}{l}67.31 \% \\
(\mathrm{male})\end{array}$ & $\begin{array}{l}32.69 \% \\
(\mathrm{female})\end{array}$ & \\
\hline Origin & $74.48 \%$ & $25.52 \%$ & \\
\hline
\end{tabular}

This work is licensed under a Creative Commons Attribution 3.0 License 


\begin{tabular}{|c|c|c|c|}
\hline & (white) & (not white) & \\
\hline $\begin{array}{l}\text { Socio- } \\
\text { professional } \\
\text { category }\end{array}$ & $\begin{array}{l}20 \% \\
(\mathrm{CSP}+)\end{array}$ & $\begin{array}{l}80 \% \text { (other } \\
\text { professions) }\end{array}$ & $\begin{array}{l}\text { Including... } \\
+/-40 \% \\
\text { (services and } \\
\text { salespersons) }\end{array}$ \\
\hline Age & $60 \%(19-49)$ & $\begin{array}{l}40 \% \text { (other } \\
\text { ages) }\end{array}$ & \\
\hline Disability & $\begin{array}{l}98.29 \% \\
\text { (without } \\
\text { disability) } \\
\end{array}$ & $\begin{array}{l}1.71 \% \\
\text { (disability) }\end{array}$ & \\
\hline
\end{tabular}

Source: Baromètre de la diversité 2012 (CSA)

http://www.csa.be/documents/1712

In conclusion, Melting Pot is one of the only series produced by French-speaking television in Belgium. Usually, media from the Frenchspeaking part of the country do not pay particular attention to diversity. It is thus interesting to consider how the series presents the French-speaking Belgians on the screen.

\section{Melting Pot}

Melting Pot is the story of Astrid, a landlady who tries to save her pub (named the Melting Pot) from bankruptcy during the first season and from destruction during the second and third seasons. Astrid has a son, Philippe, a mother, Elisabeth, some friends, some employees and recurring customers. Each recurring character has a love interest and is the subject of a secondary narrative. Astrid has to deal with the pub's owner and his daughter who want to sell the building and therefore try to evict her and close the pub.

The pub is located in a very specific district of Brussels: the Marolles. This area can be defined as historic, poor and multicultural. These characteristics are, in a way, paradoxical. The Marolles represents the authentic Brussels. The district is one of the oldest in Brussels, and the Rue Haute, the street on which the pub is located, follows the route of an ancient Roman road. This is therefore a place where the genuine culture of Brussels, for instance the Brusseleer dialect, can be found.

However, the Marolles is also a part of the city where rents are not very high and is thus inhabited by working-class people and immigrants. As such this district is also among those which are most characterised by new cultures, new languages and newcomers. Between 9 and $10 \%$ of the total 
population of Belgium consist of foreigners, but this proportion is higher in the City of Brussels, at 29.6\% (Belgian government figures for $2008^{1}$ ).

Locating a television series in this district opens up a wide range of possible plots. It could examine the relations between people who have lived in Brussels for several generations and newcomers, thus raising the issue of the Brussels identity. The story line could also observe the relationship between the various cultures of the inhabitants of the Marolles. Does the RTBF take the opportunity to tackle these topics?

\subsection{The characters}

The characters in Melting Pot are mainly white francophone Bruxellois. Thus the series mainly represents a group which is a minority in Belgium as a whole, but which is of course the majority in Wallonia and Brussels (and the audience of the RTBF).

\footnotetext{
${ }^{1}$ See figures on the Directorate-general Statistics and Economic information website : http://statbel.fgov.be/fr/statistiques/chiffres/population/structure/natact, http://statbel.fgov.be/fr/modules/publications/statistiques/population/downloads/pop ulation_nationalite_belge_et_etrangere.jsp.
} 
Table 7. Characters of Melting Pot

\begin{tabular}{|c|c|c|}
\hline Main characters & $\begin{array}{l}\text { Secondary } \\
\text { characters }\end{array}$ & $\begin{array}{l}\text { Occasional } \\
\text { characters }\end{array}$ \\
\hline $\begin{array}{l}\text { Astrid (pub landlady)* } \\
\text { Philippe (Astrid's son)* } \\
\text { Elisabeth (Astrid's } \\
\text { mother)* } \\
\text { Stéphanie(Philippe's } \\
\text { girlfriend) } \\
\text { Karine Van Damme } \\
\text { (Philippe's new girlfriend } \\
\text { and Baudouin's } \\
\text { daughter)* } \\
\text { Baudouin Van Damme } \\
\text { (brewery owner)* } \\
\text { Frédéric Vandesande (pub } \\
\text { owner)* } \\
\text { Delphine (Frédéric } \\
\text { Vandesande's daughter) } \\
\text { Rudy Vervloet } \\
\text { (policeman)* } \\
\text { Mickey (Astrid's barman) } \\
\text { Annelies (policewoman) } \\
\text { Mohamed (policeman) }\end{array}$ & $\begin{array}{l}\text { Gérard } \\
\text { Godefroid } \\
\text { (Sabena pilot, } \\
\text { customer) } \\
\text { Jos and Irène } \\
\text { (Astrid's } \\
\text { accountant and } \\
\text { his wife)* } \\
\text { Pierrot } \\
\text { (homeless, } \\
\text { customer) } \\
\text { David (Elisabeth's } \\
\text { lover)* } \\
\text { Cathy (former } \\
\text { Miss } \\
\text { Molenbeek)* } \\
\text { Pat (policeman) } \\
\text { Mr Verbeek } \\
\text { (politician) } \\
\text { Léopold } \\
\text { (Philippe's } \\
\text { father) }\end{array}$ & $\begin{array}{l}\text { Valentine (NGO } \\
\text { employee) } \\
\text { Laura (Pierrot's } \\
\text { daughter) } \\
\text { Mr Yamamoto } \\
\text { Japanese tourist } \\
\text { agent) } \\
\text { The photographer } \\
\text { Mr André } \\
\text { (Baudouin's } \\
\text { assistant) } \\
\text { Maxence (Mickey's } \\
\text { boyfriend) } \\
\text { Claudio (Mickey's } \\
\text { father) } \\
\text { Albert (Elisabeth's } \\
\text { ex- husband) } \\
\text { Etienne's (Cathy's } \\
\text { former lover) wife } \\
\text { Emir Zaroukian } \\
\text { (criminal) } \\
\text { Vladimir (criminal) } \\
\text { Boris (criminal) } \\
\text { Rudy's lawyer } \\
\text { The singer from } \\
\text { Charleroi (Rudy's } \\
\text { challenger) } \\
\text { Christophe } \\
\text { Deborsu (RTBF } \\
\text { journalist) } \\
\text { Tanguy Dumortier } \\
\text { (RTBF journalist) } \\
\text { Olivier Maroy } \\
\text { (RTBF journalist) } \\
\text { François de } \\
\text { Brigode (RTBF } \\
\text { journalist) } \\
\text { Armelle (RTBF } \\
\text { presenter) } \\
\text { Adamo (Singer)* } \\
\text { Claude Barzotti } \\
\text { (Singer) } \\
\text { (Siror }\end{array}$ \\
\hline
\end{tabular}




\begin{tabular}{|c|c|c|}
\hline 13 characters & 9 characters & 21 characters \\
\hline $\begin{array}{l}\text { Including } 1 \text { Flemish and } 1 \\
\text { Arab-Belgian }\end{array}$ & Including 1 Jewish & $\begin{array}{l}\text { Including } 1 \text { Afro- } \\
\text { Belgian, } 1 \text { Asian, } 3 \\
\text { Eastern European, } 2 \\
\text { Italian-Belgian }\end{array}$ \\
\hline
\end{tabular}

* Characters present during the three seasons

Real persons playing themselves

White francophone Bruxellois

Of the forty-three recurring characters, ten are not the usual white and francophone Bruxellois. But are they representative of minorities? One character is not Belgian and is not living in Belgium. David lives in Israel and comes to Brussels to visit his friend Elisabeth. Valentine is black, but she is Belgian. Thus these two characters do not belong to minorities, the first one as he is a foreigner, the second one as she belongs to the francophone majority ${ }^{2}$.

Eight characters represent minorities. Seven of them belong to the immigrant population. The Belgian singers, Salvatore Adamo and Claude Barzotti $^{3}$, belong to the Italian-Belgian community that migrated to Belgium after World War II, whose members are now well integrated in the Belgian population. Mohammed is of Arabic origin. He is a secondgeneration immigrant of Belgian nationality. Yamamoto comes from Asia (the country is not specified). He is a tourist agent and generally comes to the pub with some Japanese tourists. Emir, Boris and Vladimir belong to the Eastern European community. Their precise origin is not known. These seven characters represent the multiculturalism of the Belgian capital. The last character, Annelies, is Flemish. She belongs to the majority in Belgium ( $60 \%$ of the Belgian population is Flemish) but to the minority in Brussels (where probably only 10 to $20 \%$ of the population is Flemish).

Table 8. The origin of the 43 characters in Melting Pot

\begin{tabular}{|l|l|l|l|}
\hline \multicolumn{3}{|l|}{33 white francophone Belgians } \\
\hline 10 others & 1 Afro-Belgian \\
\cline { 2 - 4 } & 1 Israeli & \multicolumn{2}{|l|}{ Eastern } \\
\cline { 2 - 4 } & 8 representing & 7 immigrants & 3 Europeans \\
& minorities & & 2 Italian-Belgians \\
& & 1 Arab-Belgian \\
& & & 1 Asian-Belgian \\
\hline
\end{tabular}

\footnotetext{
${ }^{2}$ For the analysis, we regard the series as made by Francophones for Francophones. Francophones are thus the majority. Moreover the Marolles is a francophone area.

${ }^{3}$ Adamo and Barzotti are real and are famous Belgian singers whose Italian origin is well known. They are guest stars playing their own part in the series.
} 
In conclusion, with seven characters belonging to ethnic minorities, i.e. $16 \%$ of the cast, Melting Pot is not quantitatively representative of the reality, as $30 \%$ of the Brussels population comes from immigration. Neither is Melting Pot representative of the Flemish population of Brussels. Annelies is the only such character: she represents $2.5 \%$ of the cast, whereas the Flemish people represent 10 to $20 \%$ of the population of Brussels.

It is also interesting to notice that the characters representing the ethnic minorities are mainly occasional characters. This indicates that they do not really have power or significance in the narrative. In addition, the only three real villains are Eastern European, which could be seen as stereotypical. Only two minority characters (Mohamed and Annelies) are among the main ones. In quantitative terms this is insignificant, but, as they are the Arab-Belgian and the Flemish characters, their role could be qualitatively important. We will verify this hypothesis by analyzing the themes developed in the series.

\subsection{The themes}

There are two main stories in the series. The first is about the preservation of the pub and Astrid's attempts to save it from bankruptcy. The implicit theme here is the conflict between old and new, heritage and modernisation, authenticity and capitalism. The second theme revolves around the love stories of the members of the family, all of whom have a love interest in another character. The representation of communities, minorities, languages and cultures is not one of the main themes of the show, although it does appear in the secondary plots.

The discourse on minorities focuses on three secondary characters: the policemen. The relationship between Annelies and Rudy represents the linguistic conflict. She is Flemish and he is a French-speaker. She appears at the beginning of the second season, and their love story stretches from the second to the third season. In the first episodes in which Annelies appears, Rudy tries to speak Flemish to prove his goodwill. In the last episode of the second season, they sing a premonitory song: "Je t'aime in beide talen, ik houd van je dans les deux langues. L'amour est plus fort que nos différences linguistiques" ("I love you in both languages. in both languages I love you. Love is stronger than our linguistic differences") where French and Flemish are mixed. They finally manage to be together and move into a flat located on Peace Street. We have seen that quantitatively, the representation of the Flemish is weak, as Annelies is the only Flemish character. However, the fact that she is involved in a love story explicitly representative of the linguistic conflict is enough to give

This work is licensed under a Creative Commons Attribution 3.0 License 
importance to this topic. And the discourse about it is positive: goodwill is enough to live in peace.

Mohamed, the third policeman, carries the topic of immigration. Although this character also appears during the second season, this topic is mainly developed in the third season. Mohamed participates in an advertisement for the police in which he affirms that: "Policing could be a job for you even if you weren't born in Belgium" (Episode 3.1). When he is living in Rudy's apartment, we see that their lifestyles are not exactly the same. This forces them to formulate rules. But the most important story line about Mohamed is his search for a flat, in which he has to contend with racism. For instance, one Landlord, hearing that he speaks with an accent, untruthfully claims that the flat has already been taken. Mohamed works on his accent and his appearance (he wears a suit), but he does not understand why he has to do all this just "because his parents came from Morocco 40 years ago" (Episode 3.5). Sometimes, however prejudice appears where you would not expect. An Arab landlord refuses to rent him a flat because he is a policeman, and therefore someone who is corrupt, an informer, a traitor.

These secondary plots are not particularly complex. The characters' characterisation is quite obvious: the Flemish character has a Flemish accent, she falls in love with Rudy, who is too shy to make a move; the Arab-Belgian likes rap music, some of his friends are in trouble with the law, and he contends with racism. However, although the plots and characters are stereotyped, and although they are only secondary elements, they do exist and the series regularly comes back to them.

\subsection{The symbolic link between the Marolles, Brussels and Belgium}

Besides plot developed around characters, another way to explore the representation of communities is by understanding the symbol of the Melting Pot (the pub) and those who work or drink there themselves. Sometimes, the microcosm represents the Marolles, sometimes Brussels and sometimes Belgium.

The Melting Pot is the symbol of the Marolles. Astrid generally compares her pub, her customers or herself to the district. For instance, when Philippe asks her to increase the price of beer to make more profit, she answers that her customers are unemployed and cannot afford a beer for $€ 1.70$. The Melting Pot is a place for the people of the Marolles. Later, she refuses to open another pub in another district, the Halles Saint Géry, because she wants to stay in her pub with the people she likes, who cannot afford the prices charged for beer in that district. The Melting Pot belongs to the district. When Astrid is running for the city council, she asks to be 
the leading candidate, as she will get the votes of her customers, but also the other shopkeepers, the policemen, immigrants, the Flemish, and homosexuals. She is the candidate of the district. She literally represents the district.

The Melting Pot represents Brussels. The microcosm is also representative of the whole city. Pierrot lost his daughter several years ago when his wife took her to Namur, another Belgian city apparently far enough away to tear families apart. Rudy has a conflict with another singer, who claims he stole his song for the Eurovision contest. It is clearly established that Rudy is from Brussels and the other singer is from Charleroi. The conflict is not only between men but between cities. However, it is when Astrid takes part in the local elections that this topic is the strongest. She joins the "True Bruxellois Party" (as a politician puts it in Episode 3.1) and in her manifesto, the pub and the population of the city are the same thing: saving her pub means helping the Bruxellois and vice-versa. After all, her pub is the oldest in Brussels. Therefore, when the name of the party changes from "Brussels Label" to "Melting Pot Brussels Label", nobody complains as "the Bruxellois know that the city is a melting pot". This is a pun on the name of the pub and the expression 'melting pot' (which has the same meaning in French and in English).

The microcosm as representative of Brussels allows the producer to add some 'typical Brussels' effects. The Brusseleer dialect is mainly used in the dialogue, and certain typical dishes, typical names for the characters, and typical locations also give the narrative a distinctive Brussels colouring.

Table 9. Examples of 'typical Brussels' items

\begin{tabular}{|l|l|}
\hline Brusseleer dialect & $\begin{array}{l}\text { Mamke (mummy), nom de dom (swearword), } \\
\text { buntje (to have a crush on someone), broll (thing } \\
\text { or mess), filleke (little girl), en stoemeling (on the } \\
\text { sly), un pèye (a chap), c'est tof ça (it is great), } \\
\text { criminelzat (drunk), t'sais (the equivalent of “you } \\
\text { know" in oral discourses), stût (problem), vieux } \\
\text { schnock (old jerk), Karineke (familiar way to call } \\
\text { someone, here Karine, literally meaning "little } \\
\text { Karine"), volle gas (quickly), echte Brusseleer (real } \\
\text { Bruxellois) }\end{array}$ \\
\hline $\begin{array}{l}\text { Typical } \\
\text { surnames }\end{array}$ & $\begin{array}{l}\text { Vandesande, Van Damme, Lombaerts, } \\
\text { Godefroid }\end{array}$ \\
\hline $\begin{array}{l}\text { Typical dishes } \\
\text { or names for } \\
\text { food }\end{array}$ & $\begin{array}{l}\text { Stoemp saucisse, waterzooï, Bush (a brand } \\
\text { of beer), pils (usual beer), chicons (Belgian } \\
\text { word for chicory) }\end{array}$ \\
\hline $\begin{array}{l}\text { Typical places } \\
\text { The School of La Cambre (an art school in } \\
\text { Brussels), rue Haute (a street, in the }\end{array}$ \\
\hline
\end{tabular}

This work is licensed under a Creative Commons Attribution 3.0 License 


\begin{tabular}{|l|l|}
\hline Marolles), les ascenceurs du Palais de Justice \\
(a monument near the Court of Justice), \\
Chez Maman (a famous gay cabaret in \\
Brussels), la place du jeu de balle (a square \\
where there is a famous flea market every \\
Sunday), Comme chez soi (a renowned \\
restaurant in Brussels)
\end{tabular}

The Melting Pot stands for Belgium. Ultimately, the microcosm is also the symbol of Belgium. During the first season, a voice-over presents the story at the beginning of each episode. It says: "Once upon a time was a pleasant pub, picturesque, warm. A little like Belgium, in a way". Those who own and run the pub have the names of royal family members: Astrid, Philippe, Elisabeth, Leopold, Baudouin... When Elisabeth recounts the history of the pub, it appears that major events took place there. According to her, the revolution of 1830 did not begin in the La Monnaie theatre but in the Melting Pot and it was there that Leopold II decided to invade the Congo. Some customers are also symbolic of a wider population, such as the pilot who used to work for Sabena and is still traumatised at having lost his job there. Sabena, the Belgian airline that went bankrupt in 2001, was a major company in Belgium and its bankruptcy was a huge shock for the population. When Astrid participates in a political debate, although the elections are local, she is invited onto a national programme giving the impression that Astrid represents all Belgians and not just the inhabitants of Brussels.

Just as there are certain typical Brussels elements in the narrative, so too there are some typically Belgian touches. The most obvious is probably the fact that every main character has the first name of a member of the Belgian royal family. There are also allusions to famous television or radio programmes, to well-known journalists or presenters, and to some Belgian singers. Probably the most obvious tribute to a Belgian singer is the closing sequence of each episode. Astrid is a fan of Salvatore Adamo, a Belgian crooner. At the end of each episode, she is usually listening to his songs in order to cry, to celebrate, or to relax and she dreams that he is there and she is dancing with him. And the viewers see her daydreams. In Melting Pot, Belgian pieces of music and Belgian singers participate in the soundtrack, but also contribute to the 'typically Belgian' atmosphere.

Table 10. Examples of 'typically Belgian' items

\begin{tabular}{|l|l|}
\hline $\begin{array}{l}\text { Names of } \\
\text { members of the } \\
\text { royal family }\end{array}$ & $\begin{array}{l}\text { Astrid, Elisabeth, Philippe, Baudouin, Léopold, } \\
\text { Delphine }\end{array}$ \\
\hline Belgian singers & $\begin{array}{l}\text { Salvatore Adamo, le Grand Jojo, Axelle Red, Sandra } \\
\text { Kim, Claude Barzotti, Plastic Bertrand, Lio }\end{array}$ \\
\hline
\end{tabular}

This work is licensed under a Creative Commons Attribution 3.0 License 


\begin{tabular}{|l|l|}
\hline Belgian company & Sabena \\
\hline TV shows and & The characters watch the news broadcast, Strip Tease \\
media stars & (TV show), Le Jardin extraordinaire (TV show), the \\
& Eurovision song contest (TV show), Mise au point \\
(TV show), Raoul Reyers (radio presenter), Armelle \\
(TV show presenter), Christophe Deborsu \\
(journalist), Tanguy Dumortier (journalist) and \\
Olivier Maroy (journalist)
\end{tabular}

Once again, the elements mentioned here are quite simplistic. The Marolles is represented by the price of beer and poor people; Brussels is reduced to typical places, dishes, and the Brusseleer dialect; Belgium is symbolised by the royal family, Congo and Sabena. However, the narrative offers a more complex representation than may seem to be the case, as several layers combine to create a tangled network of meanings.

\section{Conclusion}

The RTBF is the public broadcaster of the French-speaking community in Belgium. That community is a minority in the country (less than $50 \%$ of the population), but as French is one of the national languages, the RTBF cannot really be categorised as a minority media outlet. Melting Pot offers a simplified representation of minorities: only a few characters come from minorities, they are mainly occasional characters, they are very stereotyped, and some of them are the villains. White Frenchspeaking characters are virtually the only ones to benefit from more complex characterisations. Although the story is set in the Marolles, which is a district of contrasts in Brussels with its combination of historic Bruxellois and newcomers, and which could be thematically promising in terms of themes, topics linked to diversity are only part of the secondary plots and are treated in a stereotyped way. In the series Francophones are the majority and this proves that, in a way, the RTBF is not a minority broadcaster for the French-speaking Belgians. This is quite logical if we bear in mind that the RTBF only broadcasts in the French-speaking territory, where it behaves like a majority broadcaster for the Frenchsspeaking majority. It should also be noted that Melting Pot does not promote diversity any more than the other television channels in the French-speaking community in Belgium. We saw that the body that supervises audiovisual media in Wallonia regrets that the typical character on television is male, white, rich, adult and not suffering from any visible disability. The only respect in which Melting Pot does better than average is with regard to socio-professional category: the characters in the series tend to be poor.

However, the series offers also a complex representation of identities. The microcosm is simultaneously - without any open conflicts 
but still paradoxically - representative of the Marolles, Brussels and Belgium. Of course, strong affiliation to one of these levels could exclude identification with the others, but this is not the case. Several levels of identity are intertwined in the series. This again underscores the fact that Melting Pot is a francophone series, produced by Francophones for Francophones, as it is far from certain that the Flemish consider Brussels, Flanders and Belgium to be equivalent. It could also suggest that Melting Pot is, after all, a series made by a minority conscious of the difficult context and trying to overcome problems. The francophone notion that Brussels is the same thing as Belgium, that the country is still unified, and that in spite of the linguistic conflict, at in the end, goodwill is enough for harmony these things are representative of an optimistic point of view.

Finally, we must underline that the RTBF is not a strong player as a producer of series in Belgium (Flemish media produce a lot more fictional shows), in Europe (where the competition from France is tough), or in the world. The RTBF lacks experience, and we saw that it is still looking for the right format for its series. The existence of Melting Pot and the other series is already a minor miracle, and maybe its representation of minorities will improve with time. 


\section{Corpus}

Melting Pot Café, 3 seasons of 6 episodes, RTBF \& Kafka Pictures, screenwriter: Jean-Luc Goossens, Executive producer: Arlette Zylberberg, 2007-2010.

\section{References}

Antoine, F. \& F. Heinderyckx. (March 2011). Etat des lieux des médias d'information en Belgique francophone. Brussels, Belgium: Parlement de la Communauté française de Belgique Wallonie-Bruxelles. Retrieved from http://egmedia.pcf.be/wpcontent/uploads/2011/03/EGMI EDL fullv6 5.pdf.

CSA, Eléments constitutifs du nouveau contrat de gestion de la RTBF. Contribution du Conseil supérieur de l'audiovisuel. Audition du 8 mars 2012. Commission audiovisuel du Parlement de la Fédération Wallonie-Bruxelles. Brussels, Belgium: Conseil Supérieur de l'Audiovisuel. Retrieved from http://www.csa.be/documents/1716.

Monaux, L. (2011). La RTBF en 2010, Identité \& complémentarité. Rapport annuel 2010. Brussels, Belgium: Bruno Deblander éditeur responsable. Retrieved from http://ds.static.rtbf.be/article/pdf/rtbf ra2010 1-1310718143.pdf.

Anonymous. (without date). "Belgique", Wikipedia. Retrieved from http://fr.wikipedia.org/wiki/Belgique

Hanot, M. (2011). Baromètre, Diversité, Egalité 2011. Brussels, Belgium: Marc Janssen éditeur responsible. Retrieved from http://www.csa.be/documents/1712.

Anonymous. (24 March 2009). American fiction is still overwhelmingly dominant on European television screens but is giving way to nationally produced fiction. Press release, Strasbourg, France: The European Audiovisual Observatory. Retrieved from http://www.obs.coe.int/about/oea/pr/a08vol2.html.

Anonymous. (without date). Structure de la population selon la nationalité actuelle. Brussels, Belgium: Directorate-general Statistics and Economic information. Retrieved from http://statbel.fgov.be/fr/statistiques/chiffres/population/structur e/natact.

Anonymous. (15 March 2012). Population - Chiffres population 1990-2011. Brussels, Belgium: Directorate-general Statistics and Economic information. Retrieved from http://statbel.fgov.be/fr/modules/publications/statistiques/pop ulation/population - chiffres population 1990-2011.jsp.

Anonymous. (without date). Population de nationalité belge et étrangère $d u$ 1/01/1990 au 1/01/2008. Brussels, Belgium: Directorate-general Statistics and Economic information. Retrieved from 
Alternative Francophone vol.1, 6(2013): 1-19

http://ejournals.library.ualberta.ca/index.php/af

http://statbel.fgov.be/fr/modules/publications/statistiques/pop ulation/downloads/population nationalite belge et etrangere.jsp

This work is licensed under a Creative Commons Attribution 3.0 License 